\title{
Capital Inflows and the Real Exchange Rate: A Comparative Study of Asia and Latin America*
}

\author{
Prema-chandra Athukorala \\ Research School of Pacific and Asian Studies \\ Australian National University \\ Prema-chandra.athukorala@anu.edu.au \\ and \\ Sarath Rajapatirana \\ American Enterprise Institute \\ sr@aei.org
}

\begin{abstract}
The nexus of real exchange rate $(R E R)$ and capital inflows is examined through a comparative analysis of the experiences of emerging market economies in Asian and Latin America during the period 1985-2000. It is found that the degree of appreciation in RER associated with capital inflow is uniformly much higher in Latin American countries compared to their Asian counterparts, despite the fact that the latter experienced far greater foreign capital inflows relative to the size of the economy. The econometric evidence suggests that both the composition of capital flows and differences in the degree of response of RER to capital flows matter in explaining these contrasting experiences. While $R E R$ appreciation is a phenomenon predominantly associated with other (non-FDI) forms of capital inflows $(O C F W)$, a given level of $O C F W$ brings about a far greater degree of appreciation of the real exchange rate in Latin America where the importance of these flows in total capital inflow is also far greater. On the policy front, Asian countries seem to have used fiscal contraction and nominal exchange rate adjustment more effectively to cushion the RER against the appreciation pressure of capital inflows. There is, however, no evidence to suggest that sterilized intervention can generate a lasting impact on the real exchange rate.
\end{abstract}

Key Words: real exchange rate, capital flows, foreign direct investment

JEL Classification: F41, F32, O11

Forthcoming in The World Economy (Max Corden Festschrift Issue), 2003 


\title{
Capital Inflows and the Real Exchange Rates: A Comparative Study of Asia and Latin America
}

\author{
Prema-chandra Athukorala and Sarath Rajapatirana
}

\section{INTRODUCTION}

The string of financial crises in emerging-market economies in the 1990s and the global reverberations that followed them have added new impetus to the debate on how to reconcile international capital mobility with domestic economic stability and developmental priorities in investment receiving developing countries. The unqualified enthusiasm for promoting capital flows to aid economic advancement in these countries has given way to a new emphasis on finding ways and means of ameliorating unfavorable side effects of 'too much' capital inflow. At the center of this debate is what Corden (1994, p. 8) calls the 'real exchange rate problem'- the possibility that capital inflows bring about an appreciation of the real exchange rate (the relative price of traded to nontraded goods) with adverse affects on traded-goods production in the domestic economy.

If a country relies on foreign capital (or any other inward transfer) to maintain high levels of domestic absorption, it is natural for the real exchange rate to appreciate, regardless of the exchange rate regime. The increased spending on traded goods will be accommodated through an increase in the trade deficit with no adverse impact on the real exchange rate. By contrast the excess demand on non-traded goods will result in an increase in the price of these goods relative to that of traded goods. This price adjustment occurs either through an appreciation of the nominal exchange rate under a floating

$\bullet$

The authors would like to thank Montek Ahluwalia, Richard Cooper, Allen Gelb, Morris Goldstein, Will Martin, Martin Wolf, Judith Dean and other participants of the Corden festschrift conference held on 19 April 2002 at the Paul H. Nitze School of Advanced International Studies, The Johns Hopkins University; and Satish Chand, Ross Garnaut, Hal Hill and Ross McLeod for helpful comments. Thanks are also due to Archanun Kohpaiboon for excellent research assistance. 
exchange rate system or through an increase in nominal prices of non-traded goods in a fixed exchange rate regime, or through a mixture of the two processes in an intermediate (fixed-but-adjustable) regime. But the problem with this natural (equilibrium) phenomenon is that capital inflows may well be temporary, and hence in due course real depreciation is likely, which may require a painful and politically unpalatable economic adjustment. At the same time, capital inflow-induced real appreciation can have adverse impact on economic adjustment during the boom period, hampering the country's ability to face such an eventuality. It tends to discourage traded-good sectors, divert resources to over-consumption or investment in low yielding non-tradable goods sectors. Moreover persistent real appreciation could well set the stage for a speculative attack on the national currency, putting an end to the very economic boom fueled by capital inflows. ${ }^{1}$

There is a sizable literature on the patterns and determinants of capital flows to Asia and Latin America and problems of macroeconomic management in the context of increased capital mobility. ${ }^{2}$ However to our knowledge there has not been any systematic comparative analysis of the nexus of real exchange rate and capital flows encompassing countries in the two regions. The general perception in the literature is that the East Asian countries have done fairly well in absorbing capital inflows without a seriously damaging impact on economic performance operating though real exchange rate appreciation. However, there is a number of important issues yet to be answered relating to the comparative performance of these countries to inform the on-going debate. Can the observed greater susceptibility of the real exchange rate in Latin American countries to capital inflows be explained in terms of differences in policy responses alone? If so what are these policies? Are there some region-specific factors (rooted in the macroeconomic policy history, for example), which make Latin American countries more vulnerable to real appreciation associated with a given level of capital inflow? Does the

\footnotetext{
${ }^{1}$ In the recent literature on currency crises, persistent appreciation of the real exchange rate (adjusted for fundamentals) has been identified as a major factor in setting the scene for a crisis. This is because a persistent real appreciation implies that economic fundamentals of the country may not permit the authorities to defend the currency successfully in the event of a speculative attack. (Kaminsky et al. 1997, Sachs, Tornell and Velasco 1995).

2 See for instance Calvo et al. (1994 and 1996), Gavin et al. (1996), Corbo and Hernadez (2000), Dornbusch and and Werner (1996), Edwards 2000, Ito (2000), Larian (2000) and Fernandez and Montiel (2000).
} 
composition of capital inflows matter? In particular, is foreign direct investment different from other capital inflows in its impact on the real exchange rate?

This paper aims to examine these and related issues through a comparative analysis of the experiences of eight Asian economics (China, India, Indonesia, Korea, Malaysia, The Philippines, Singapore and Thailand) and six Latin American countries (Argentina, Brazil, Chile, Colombia, Mexico and Peru) during the period 1985-2000. ${ }^{3}$ The choice of the sample was primarily dictated by data availability, but it contains all major countries in the two regions which were exposed to significant international capital flows in the 1990s. There are notable differences among these countries in terms of the 'official' (de jure) exchange rate regime adapted during the study period, ranging from a fixed rate (currency board) regime in Argentina to a 'freely floating' regimes in the Philippines. But the available evidence on the actual exchange rate practices of these countries (Corden 2002, Edwards 2000, Williamson and Mahar 1998) amply supports the view that during most of the period under study all countries de facto maintained fixed (but adjustable) exchange regimes, with the United States dollar as the key intervention currency. Thus, our country sample provides a near laboratory setting for studying issues involved in maintaining a fixed exchange rate commitment while averting real exchange rate appreciation in face of high capital inflows.

We could not think of a better subject for a paper in honor of Max Corden. During the past four decades of his illustrious career he has made a notable contribution to broadening our knowledge of the real exchange problem both through policy-oriented work and, more importantly, through analytical research. Relating to the latter, starting with his seminal 1960 paper, he has played a key role in developing and popularizing the dependent economy model (recently renamed as 'Salter-Swan-Corden-Dornbusch model' by Corbo and Fisher 1995, p. 2863) which is the workhorse of policy-oriented research in the sphere of macroeconomic adjustment in developing countries.

3 The original research plan for this paper aimed to cover a longer time period, from 1975-2000 with a view to undertaking a comparative analysis of the capital inflow boom in the 1990s and with the previous boom during 1978-82. It was subsequently realized that the two episodes cannot be meaningfully analyzed with a unified framework because the previous episode was markedly different from the latter episode in terms of the international environment, type of flows, economic structures of the recipient countries and policy responses. 
The rest of the paper is organized as follows. Section 2 provides a comparative overview of trends and patterns of capital inflows to the two regions. Section 3 takes a first look at the relationship between capital flows and the real exchange rate through an examination of time-series plots. Section 4 undertakes an in-depth empirical analysis of the role of capital flows among other variables impacting on the real exchange rate behavior, with emphasis on similarities and differences between countries in the two regions. This section proceeds in two steps. First, a single-equation model is formulated and estimated to delineate the impact of capital inflows on the real exchange rate while controlling for

other relevant variables suggested by the theory. Second, the econometric estimates are combined with data on the key variables for individual countries to make inferences about the observed differences between the two regions. The key inferences are summarized in the final section.

\section{TRENDS AND PATTERNS OF CAPITAL INFLOW}

The post-Second-World-War era has witnessed two major episodes of capital inflow surges to developing countries. The first was associated with the petrodollar recycling process following the oil price increases in the 1970s. The episode started in the second half of the 1970s and lasted until the onset of the debt crisis is 1982 following the Mexican debt moratorium. The second episode, which is the focus of this paper, began in the latter half of the 1980s and gathered momentum in the first half of the 1990s, with total net inflows to developing countries and flows to many individual countries surpassing the early-1980s peaks by 1994. The flows slowed following the Mexican crisis in late 1994 and plummeted following the onset of the Asian crisis in the second half of 1997. Unlike the previous boom, which was propelled predominantly by a onceand-for all event, the boom of the 1990s has been the outcome of pull-factors - those related to better opportunities in the recipient countries - and push factors - those related to lower interest rates and slowdown in economic activity in industrial countries. Some of these factors (for instance global asset diversification of pension funds in developed countries, rapid internationalization of production in high-tech industries, domestic 
market reforms in developing countries) are of long-term nature in their effect. ${ }^{4}$ Thus, the indications are that large capital flows are here to stay as an important global economic phenomenon.

Net private capital flows to the emerging markets (developing countries and transition economies) increased from an annual average of less the US \$10 billion in the latter half of 1980s to nearly US \$200 billion by the mid-1990s (Figure 1). ${ }^{5}$ Of total annual flows to these countries during 1990-1997, almost three-fourths were absorbed by countries in Asia and Latin America. In the early 1990s, total flows to Asia and Latin America were roughly similar in magnitude, but during 1993-1996 inflows to Asia surpassed those to Latin America by a wide margin.

\section{Insert Figure 1 about here}

The decline in flows caused by the Mexican crisis in 1994 was by and large confined to Mexico and Argentina. Thanks to the swift actions under the IMF-US Treasury deal, its repercussion on Asia (and the rest of the world) was minimal. Total flows to both regions expanded well into 1997. However, the repercussions of the Asia crisis on global capital mobility was much more dramatic. Total flows to Asia plummeted from US\$114 billion in 1996 to US\$19 billion in 1997 and contracted by a staggering US\$55 billion in 1998, and net inflows to the region remained virtually zero until $2001 .^{6}$ Reflecting the global reverberation of the Asian crisis (which was subsequently amplified by the Russian and Brazilian crises) total flows to Latin America declined from US\$68

\footnotetext{
${ }^{4}$ Relative importance of the pull and push factors has been extensively debated in the literature. See for instance Corbo and Hernandez 2000 and the works referred to therein.

5 Data on total capital flows (public + private) covering the entire period and with required disaggreation are not readily available. But private capital flows depicted in Figure 1 provide an accurate picture of the trends in total capital flows because net public flows dwindled from about the late-1980s reaching less than US\$ 10 billion (less than 5\% of total annual flows) by the mid-1990s.

6 In the five crisis-affected countries in Asia (Thailand, Malaysia, Indonesia, Korea and the Philippines) the turnaround in capital flows during 1996-97 amounted to US\$105 billions, more than $10 \%$ of the combined GDP of these combined economies.
} 
billion to US\$ 39 billion in 2000, arguably a much less dramatic decline in the circumstances.

During the 1977-82 episode, bank loans (and other related flows) accounted for the bulk (over three-fourths) of net inflows to the developing countries. By contrast foreign direct investment (FDI) and portfolio investment have dominated net flows in the 1990s. FDI has however been relatively more important in net flows to Asia compared to Latin America.

Table 1 provides summary data on total net capital flows to the 14 countries under study, distinguishing between three types of flows; foreign direct investment (FDI), portfolio investment (investment in the form of transaction and debt securities) and bank loans and other types of flows. The first two categories are essentially private flows. The third category includes trade credit (both short term and long term) and official capital flows (bilateral and multilateral loans and foreign aid). ${ }^{7}$

\section{Insert Table 1 about here}

It is evident that, relative to the size of the economy, some of the Asian countries experienced much larger capital inflows compared to their Latin American counterparts. For instance, Malaysia absorbed inflows amounting to $10 \%$ of GDP in $1991,15 \%$ in 1992, and more than $20 \%$ in 1993 , averaging to $12 \%$ for the entire boom period of 1989-96. The average annual inflows to Thailand and the Philippines also exceeded $10 \%$ of GDP. None of the six Latin America countries experienced capital inflows exceeding $10 \%$ of GDP.

The Asian countries as a group received relatively higher share of inflows in the form of FDI. However there were considerable differences in the FDI share among the countries in the region. For instance South Korea was a net overseas foreign direct investor throughout and total net inflows to that country predominantly took the form of

\footnotetext{
${ }^{7}$ Ideally, we should disaggregate the third category into private and official flows, but required data are available only for a few countries.
} 
portfolio capital and bank borrowing. The Philippines, Thailand and Indonesia also relied on bank borrowing to a significant extent, although FDI share in total flows to these countries remained much larger compared to their Latin American counterparts. FDI accounted for the overwhelming share of net flows to China and Malaysia. FDI flows to Latin American countries (other than Chile) were basically related to privatization of state-owned enterprises, whereas in Asia, particularly in East Asia, such flows were in the form of green-field investment. There is also evidence that a relatively higher share of FDI inflows to Latin America had gone to non-traded sectors (construction and commercial services) and natural resource development, compared to Asia. In Asia FDI was by and large in traded-good sectors, mostly in export-oriented manufacturing (Ito 2000, Reisen 2000).

Finally, the data suggest that across the countries FDI flows have been less volatile among the three different types of flows. In particular during the financial crises in Mexico and the five Asian countries FDI flows showed remarkable stability in a context where the other flows shifted sharply into the negative territory. Interestingly, net FDI flows to South Korea and Thailand increased in the aftermaths of the currency collapse, aided by the newly-gained competitiveness through currency depreciation and liberalization of the FDI regimes as part of the crisis management strategy (Athukorala 2002).

\section{REAL EXCHANGE RATE-CAPITAL FLOW NEXUS: A FIRST LOOK}

This section looks at the capital flows-real exchange nexus as a prelude to the econometric analysis in the next section. The real exchange rate $(R E R)$ is measured here as the ratio of export-weighted wholesale price index of trading partner countries expressed in domestic currency relative to the domestic GDP deflator. The rationale behind the choice of this particular measure among various proxy measures of $R E R$ is discussed in the Appendix. In Figure 2, RER is plotted for each country together with net capital inflow measured as a percentage of GDP (denoted $C F W$ ). In each graph, the beginning and end of the capital inflow episode in the 1990s are demarcated with vertical lines. In Table 2, the data are summarised for the capital inflows episodes in the 1990s. 


\section{Insert Figure 2 about here Insert Table 2 about here}

The general observation that the degree of $R E R$ appreciation associated with capital inflow is uniformly much higher in Latin American countries compared to their Asian counterparts is clearly borne out by this comparison. Focusing on the capital inflow episodes (Figure 2), the real exchange rate appreciated by almost $43.5 \%$ in Argentina during its early-1990s capital inflow episode, compared to the three preceding years (Table 2). The rates of appreciation for the other five countries ranged between $14.7 \%$ (Brazil) to $33.8 \%$ (Mexico). Among the Asian countries, only the Philippines experienced a rate of appreciation that comes closer to the average level for the Latin American countries. The degrees of appreciation in Indonesia, Malaysia, Singapore, Thailand and the Philippines were rather mild, ranging from $2.3 \%$ to $11.2 \%$. In India and China, the real exchange continued to depreciate (rather than appreciate) during their inflow episode. In India, capital inflows occurred against the backdrop of a significant structural adjustment reform. Discretionary devaluation as part of this reform package seems to have offset the impact of capital inflows. ${ }^{8}$ In early 1994 China decisively reformed its exchange rate mechanism resulting in a real depreciation of the Yuan by $17 \%$ over the previous year, placing the country in a position of strength to withstand massive capital inflows in the subsequent years. The average degree of depreciation reported in Table 2 must therefore be viewed in the context of this successful, early exchange rate adjustment (Athukorala and Warr 2002, p. 50).

\footnotetext{
${ }^{8}$ In any case, thought the post-war era capital inflow to India had been small relative to the size of the economy (Athreye and Kapur 2001).
} 


\section{REAL EXCHANGE RATE-CAPITAL FLOW NEXUS: EMPIRICAL ALYSIS}

In the previous section we observed that, although there was considerable inter-country variations in the relationship between capital inflow and changes in the real exchange rate among the countries under study, the six Latin American countries experienced a uniformly higher degree of real exchange rate appreciation associated with capital inflows compared to Asian countries. In this section we proceed to probe these similarities and differences in two steps. First a single-equation model is developed and estimated using pooled time-series data for the fifteen countries to delineate the like between the real exchange rate and capital inflows while controlling for other factors. Second parameter estimates of the model are combined with data on the key explanatory variables to explain inter-group and inter-country differences.

Our model aims to explain the behavior of RER in terms of capital inflows (disaggregated into foreign direct investment $(F D I)$ and other capital flows $(O C F W)^{9}$, both measured relative to GDP) and a set of macroeconomic indicators chosen to represent policies implemented to compensate for the real exchange rate effect of capital flows. The postulated relationships between the dependent variables and the real exchange rate are firmly rooted in the Salter-Swan-Corden-Dornbush model. ${ }^{10}$

Previous studies of real exchange determination in developing countries have used capital flows as an aggregate variable encompassing all forms of flows. ${ }^{11}$ There are however strong reasons for hypothesizing that the degree of real exchange rate appreciation associated with a given level of FDI inflows tends be smaller in magnitude compared to other flows, in particular portfolio flows and bank lending (Ito 2000, Resin 2000, Lipsey 2000). Compared to other flows, FDI in developing countries has a general

\footnotetext{
${ }^{9}$ OCFW covers both private and public flows. Data are not available for most of the countries under study to treat them separately.

10 We do not intend to spell-out the dependent economy model here for want of space. The interested reader is referred to Corden 1994, Chapter 1, which contains perhaps the best, nontechnical exposition of the model.

11 Edwards and Savastano (2000) provide a comprehensive survey of various studies of real exchange rate determination (pp.488-90 and Table 13.5).
} 
tendency to concentrate more in traded goods sectors. Moreover with the on-going process of transformation in international production and rapid economic opening in investment receiving (host) countries there has been a significant increase of FDI participation in export-oriented production. This is particularly so in the East Asian countries in our country sample (Ito 2000). Thus the pressure on non-traded goods prices resulting from FDI-related activities is presumably lower compared to that arising from the other forms of capital inflow. Moreover, FDI is also not as volatile as the other shortterm flows. Therefore any possible ratchet (lingering) effect on the real exchange rate resulting from upswings in inflows is likely to be less important in the case of FDI. For these reasons we treat FDI and other capital inflows as two separate variables in our analysis and assume the effect of the former to be smaller in magnitude compared to that of the latter.

The attractiveness of a given country for FDI depends crucially on the general investment climate, which primarily reflects the cumulative outcome of economic policy reforms (Calvo et al., 1996, Feenstra 2000, Corbo and Hernandez 2000). However there is evidence that the composition of capital inflows can also be tilted in favor of FDI (and other long-term flows) through policies specifically aimed at discouraging shortterm flows. The most cited evidence of such policy engineered compositional shift comes from Chile and Colombia. ${ }^{12}$ There is also evidence from China and Malaysia ${ }^{13}$ that the government can intervene in short-term flows and still provide a hospitable environment for FDI (Corden 2002, Stiglitz 2000, Athukorala 2001, Garnaut 1999). The disaggregated treatment of capital flows in our analysis should help understand whether such policy-induced shift in the composition of capital inflows can help ameliorate the effect of total inflows on the real exchange rate.

12 See Larian 2000, pp. 11-12 and the work cited therein. Note that here we refer to composition shift, rather than the total volume, of capital inflows. Whether the Chilean and Colombian capital controls have had any dampening effect on the volume of inflow still remains a controversial issue (Edwards 2000).

13 Here we refer to the controls introduced by the Malaysian authorities on short-term capital inflows in 1994. The Malaysia capital controls introduced in 1998 were on outflows and are not relevant to the discussion here. 
The options open to policy makers to cushion the real exchange rate against pressure of appreciation arising from capital inflows under a fixed exchange rate are of three types. These are fiscal contraction, sterilizing foreign exchange market interventions and nominal exchange rate adjustment. In our model each of these policy stances are represented respectively by government expenditure (relative to GDP) $(G E X P)$, excess growth in money supply (M2) measured as the difference between growth in M2 and real GDP growth $(E X M G)^{14}$, and change in the nominal exchange rate $(D N E R)$.

In the context of an investment boom funded by capital inflows, fiscal contraction can act as an effective stabilizer in moderating the real exchange rate effect of capital inflow boom. The absorption of capital inflows would increase demand for domestic goods and the fiscal contraction would reduce it. In addition to this general demand contraction effect, reduction in government expenditure can have a favorable switching effect because government expenditure tends to be spent more on non-tradables, unlike private consumption.

The measure widely used to represent a fiscal policy stance in this type of analyses is the budgetary balance (measured as a ratio of GDP). But we believe that government expenditure is a superior indicator because in the context of an economic boom a country could well experience a 'revenue surplus', a reflection of a faster revenue growth compared to expenditure growth. Meaningful deficit comparison across countries should correct for such biases. Another problem with published data on budget deficits is that different definitions of taxation and borrowing can heavily skew the measured deficit (Sachs 1985).

When foreign capital flows into a country that has a fixed exchange rate commitment, the central bank is naturally forced to purchase excessive flows (that is build up its foreign exchange reserves) in order to maintain the 'desired' level of stability in the nominal exchange rate. However, the mere purchase of foreign currency (non-

14 This measure assumes that money demand has a unitary elasticity with respect to the real income. 
sterilized intervention) is not going to solve the problem. The increase in domestic money base (of which foreign reserves are a part) results in increase in domestic money supply, fuelling domestic inflation and appreciating the real exchange rate. But the central bank, could at least for a time, offset this effect by combining reserve accumulation through foreign exchange market intervention with the open market sale of bonds or other monetary action to reduce domestic credit expansion. The variable $E X M G$ is included in the model to test the effectiveness of such sterilized intervention in averting real exchange rate appreciation.

Sterilized intervention is a useful policy that can provide some short-term relief in the context of excessive capital inflow. But to the extent that sterilization drives shortterm interest rates higher, it may perpetrate excess capital inflows and real appreciation. This is going to be a particularly binding constraint if FDI and other long-term inflows account for a large share of total inflows. In such a case, one-to-one sterilization will likely increase the short-term interest rate leading to an increase in short-term capital (Ito 2000). Another important problem with sterilized intervention, particularly raised in the Latin American context, relates to the alleged fiscal cost; domestic market intervention of the Central Bank involves paying a higher interest rate than what is earned on accumulated foreign reserves, which are usually invested in low-yielding short-term securities (Calvo 1991). When such costs build up authorities are naturally forced to backtrack from their policy commitment to support the currency. For these reasons, sterilized intervention is generally considered a far less effective policy instrument compared to fiscal contraction in averting the problem of real exchange rate appreciation in face of large capital inflows.

The third policy instrument considered here is nominal exchange rate adjustment. Within the boundaries set by the particular exchange rate regime chosen, countries have the ability to take steps to correct from time to time the disequilibria in the fixed (but adjustable) nominal rate against the intervention currency (US\$). Such exchange rate practice has been referred to in the literature as one of the contributory factors for the success of East Asian countries to maintain the real exchange rate at realistic levels (Garnaut 1999, Krueger 1997, Reisin 2000). To test the effectiveness of such nominal 
exchange rate adjustment, we use the annual changes in the nominal exchange rate $(D N E R)$ as an explanatory variable.

In addition to the above variables, we use openness to trade (OPEN) as another variable. Previous studies on real exchange rate determination in developing countries have found this to be a significant explanatory variable (Edwards and Savastano 2001, Table 13). The underlying hypothesis is that, other things remaining unchanged, greater openness to trade tends to avert undue pressure for the appreciation of the real exchange rate. There is no unique measure of openness. Among the available alternatives, we use the Sachs-Warner binary index that takes value 1 for an open trade regime and zero otherwise (Sachs and Warner 1995)..$^{15}$

Based on the above discussion, the real exchange rate function for the ensuing empirical analysis can be specified as,

$R E R=f(F D I, O C F W, E X M G, G E X P, D N E R, O P E N, L A * O C F W, L A * F D I, L A * E X M G$, $L A * G E X P, \quad L A * D N E R, \quad L A * O P E N)$

The dependent variable $(R E R)$ is the real exchange rate index (as defined in the Appendix). An increase (decrease) in $R E R$ indicates real depreciation (appreciation). The independent variables are given below (with the signs expected for the regression coefficients in parentheses):

15 Sachs and Warner (1995) employ the following criteria Sachs-Warner (1995) employ the following policy criteria to distinguish countries with closed (inward-oriented) policy regimes from those with open (outward-oriented) policy regimes:(i) Non-tariff barrier coverage of intermediate and capital goods imports of 40 per cent or more; (ii) an average tariff on intermediate and capital goods imports of $40 \%$ or more; (iii) A black market exchange rate that is depreciated by $20 \%$ or more relative to the official exchange rate; (iv) A socialist economic system and (v) state monopoly on major exports. The trade policy regime of a given country/year is identified as open if none of the above five conditions is applicable. Alternative regression estimates based on two other widely-used alternative measures of openness - the black market exchange rate premium and the ratio of total merchandise trade (imports + exports) to GDP in traded-goods sectors (GDP net of services, construction and utilities) — produced virtually similar results. 
FDI ( - ) Foreign direct investment

$O C F W($ - ) Capital inflow excluding FDI

EXMG (- ) Excess money growth

GEXP (-) Government expenditure

DNER (+) Change in nominal bilateral exchange rate against the US dollar.

OPEN (+) Openness

and the remaining variables are the counterpart slope dummy variables for Latin America $(L A)$, where $L A$ takes value 1 for Latin American countries and 0 for the other (Asian) countries. These dummy interaction terms serve to test whether the magnitude of the each regression coefficient for Latin American countries as a group differs significantly from the estimate for the overall country sample.

The model is estimated using pooled annual data for the fourteen countries over the period 1985 to $2000 .{ }^{16}$ In addition to the variables mentioned above, we also included country-specific intercept dummies (with Thailand as the base dummy) to allow for country-specific fixed effects. For the purpose of estimation, all variables are used in natural $\log$ arithms ${ }^{17}$ so that the estimated coefficients can be directly interpreted as elasticities. Pre-testing of the explanatory variables for endogeneity (using the $\mathrm{Wu}-$ Hausman procedure) suggested that RER and $O C F W$ are jointly determined, or more precisely, $O C F W$ is positively correlated with the error term of the equation. We therefore estimated the equation using Two Stage Least Squares (TSLS), instrumentalizing that variable. ${ }^{18}$

16 The data series on OCFW and FDI were compiled from the International Financial Statistics database of the IMF. All other data series comes from the World Development Indicators database of the World Bank.

17 RER is directly converted into logarithms and DNER in measured as annual differences in logarithms. The remaining variables are first measured as ratio of GDP and converted into logarithm as $\ln (1+X)$.

18 The instruments were LIBOR, real OECD GDP, a time variable, GDP growth, gross domestic fixed capital formation (relative to GDP), lagged dependent variable, current and lagged values of other explanatory variables and country intercept dummies. 
The estimated full model is reported as Equation 1 in Table 3. In this equation, coefficients attached to three explanatory variables - EXMS, $L A^{*} E X M S$ and $L A^{*} G E X P$ are not statistically significant. The model estimated after dropping these variables is reported as Equation 2. ${ }^{19}$ To facilitate the interpretation of the results, a summary of the variables used in the regressions is presented in Table. 4.

\section{Insert Table 3 about here Insert Table 4 about here}

Both equations pass the standard $F$ test for overall significance at the one percent level. The overall fit ( $\overline{R^{2}}$ ) is highly satisfactory for an econometric exercise based on pooled cross-country data. The equations also comfortably pass the standard diagnostic tests for functional form specification (RESET), normality (JBN) and heteroskedasticity $(A R C H)$. The specification of the first-stage regression in instrumental variable estimation (IV) is amply supported by the Sargan's test. The following discussion is based on Equation 2, which is our preferred model.

Let us first consider the results for the two capital inflow variables (OCFW and $F D I$ ). For all countries on average one percent increase in $O C F W$ brings about 0.56 percent appreciation in the real exchange rate. By contract, FDI inflows are associated with depreciation (rather than appreciation)of the real exchange. The results for the respective slope dummy variables ( $L A * O C F W$ and $L A * F D I)$, however, suggest that the magnitudes of these elasticities for the Latin American country sub-group differ significantly from these overall estimates. In Latin America a one percent increase in $O C F W$ brings about, on average, 1.7 percent appreciation in the real exchange rate. The degree of depreciation associated with a one percent increase in FDI flow is much smaller (0.06 per cent) for the region compared that for the entire country sample (0.56 per cent). These estimates yield two important inferences. First, in both regions 'the real exchange rate problem' is a phenomenon specifically associated with 'other' capital flows $(O C F W)$. Second, these flows have a greater dampening impact on the real exchange in

19 This specification choice was amply supported by the Wald test for joint variable deletion. The coefficient estimates of the remaining variables are remarkably robust to the deletion of these three variables. 
Latin America compared to that in Asia. At least part of the explanation for this difference may be rooted in differences in the macroeconomic policy histories of the two regions. ${ }^{20}$ For instance, given the proven track record of maintaining macroeconomic stability, it is likely that the pressure on non-tradable prices resulting from resources transfers to the Asian countries is counterbalanced by an increase in domestic saving and investment.

Why FDI inflows tend to depreciate (rather than appreciate) real exchange rate is an interesting issue which requires further investigation. However, we believe that this result is consistent with our hypothesis that FDI generally tends to have a more tradable bias compared to the other types of capital flows. The lower magnitude of the measured relationship for Latin America may reflect differences in the output composition of FDIrelated activities in the two regions; as noted in Section 2 there is evidence that FDIrelated activities in Latin America have a greater non-tradable bias.

The coefficient attached to GEXP is uniformly applicable to both regions as the coefficient on the slope dummy variable, $L A^{*} G E X P$, is not statistically different from zero. It suggests that a one percent contraction in government expenditure to GDP ratio is associated with 3.17 per cent depreciate in the real exchange rate. Thus our results support the theoretical proposition that fiscal contraction is a powerful cushion for all countries against real exchange appreciation associated with capital inflows. This result for GEXP when combined with the data on this variable for individual countries (Table 4) provides a powerful explanation as to why the Asian countries experienced a rather mild appreciation in the real exchange rate compared to the experience of their Latin counterparts. In the former countries government expenditure has remained flat or even declined during the period of the boom. In Malaysia and Thailand government expenditure in relation to GDP declined in the wake of capital influx in the early 1990s. In Latin America, all countries except Chile government expenditure increased, and Brazil and Argentina recorded increases of more than four percentage points. The only

\footnotetext{
${ }^{20}$ For details on macroeconomic policies and experiences see Corden (1996), Little et al. (1993)
} and Edward (1995). 
Asian country to record an increase in government expenditure during the boom is the Philippines.

As already noted, the excess money growth variable $(E X M S)$ failed to yield a statistically significant coefficient and the coefficient of the other variables were remarkably resilient to its inclusion in (or exclusion from) the model. This result is consistent with the widely held views about the impotence of sterilized intervention as a policy tool in averting real exchange rate appreciation in face of high capital inflows.

Finally, the results for DNER suggest, on average one percentage point depreciation in the nominal exchange rate change translates in to 0.5 per cent depreciation in the real exchange rate. However, the coefficient estimate for the related slope dummy variable $\left(L A^{*} D N E R\right)$ suggests that the impact is rather small (0.05 per cent) for the for Latin American countries. These results are consistent with the view that the Asian countries have been more successful in averting real exchange rate appreciation through nominal exchange rate adjustment, compared to the Latin American countries (Little et al. 1993, Corden 1996, Reisen 2000). The explanation seems to lie in wellknown wage-price rigidities, in particular wage indexation, in the latter countries which serve to quickly dissipate the impact of nominal exchange rate depreciation (Little et al. 1993, Chapter 7).

\section{CONCLUSION}

In the 1990s, the major capital-importing countries in Asia have managed to cope far better with the real exchange problem associated with capital flows compared to their Latin American counterparts. The degree of real exchange rate appreciation associated with capital inflows was uniformly much lower in the Asian countries, despite the fact that some of these countries experienced far greater foreign capital inflows relative to the size of their economies. According to the results of our empirical analysis the explanation of these differences seems to lie in both country specific factors (as reflected 
in differences in the coefficients in the real exchange rate function) and policy differences (as reflected in the levels of the relevant explanatory variables).

Our econometric results suggest that the composition of capital flows matters in determining their impact on the real exchange rate. 'The real exchange rate problem' is a phenomenon predominantly associated with 'other' capital flows $(O C F W)$ and $F D I$ seems to have a salutary effect on the real exchange rate. Moreover, due perhaps to the legacy of a traumatic macroeconomic policy history, a given level of $O C F W$ brings about a far greater degree of appreciation of the real exchange in Latin America compared to Asia. This difference in the magnitude of the observed relationship, coupled with the greater importance of $O C F W$ in total capital flows to Latin American countries, seem to go a long way in expanding the relatively higher degree of real exchange rate appreciation experienced by these countries compared to their Asian counterparts.

Among the policy variables considered, fiscal contraction seems to have been used more effectively by the Asian countries to cushion the real exchange rate against the appreciation pressure of capital inflows. There is, however, no evidence to suggest that sterilized intervention can generate a lasting impact on the real exchange rate. Finally, nominal exchange rate change seems to have a significant lasting effect on the real exchange rate only in Asian countries. Due perhaps to wage-price rigidities, the impact of a given nominal exchange rate change seems to dissipate quickly in Latin American countries. 


\section{APPENDIX \\ MEASUREMENT OF THE REAL EXCHANGE RATE}

The real exchange rate $(R E R)$ is the price of traded goods relative to the price of nontraded (domestic) goods. In the absence of readily available indices of tradable and nontradable prices, the real exchange rate has to be proxied by available domestic and world price indices and nominal exchange rates. There is no unique way of constructing a proxy measure, but all commonly used measures compute the ratio,

$$
R E R=\frac{[N E R] P^{W}}{P^{D}}
$$

where NER denotes the nominal exchange rate (measured as domestic currency per foreign currency), $P W$ is an index of foreign prices and $P D$ is an index of domestic prices. NER and $P W$ are weighted averages computed across trading partner countries. The country weights may be based on export shares, import shares or, most commonly, shares based on the sum of exports and imports, although the latter has no apparent theoretical foundation.

The particular measure used differs according to the measures used for $P W$ and $P D$. Our preferred proxy measure makes use of foreign producer (wholesale) prices for $P W$ and domestic GDP deflator for $P D$.. Country weights based on export shares are used in the construction of $N E R$ and $P^{w}$ series. ${ }^{21}$ By construction, the producer price index is dominated by the prices of tradables much more than the GDP deflator. The index may thus serve as a rough proxy for the theoretical concept of the real exchange rate - the relative prices of tradable to non-tradable goods. A convenient alternative to GDP deflator as the domestic price measure in constructing the index is the consumer price index (CPI) (Edwards 1989, Athukorala and Warr 2002). Our preferred choice is the

21 For a discussion on the conceptual basis for using export weights (rather than commonly-used trade (export + import) weights) see Warr (1986). 
former, for two reasons. Firstly, GDP deflator provides a much broader, economy-wide coverage of price changes compared to CPI. Second, and perhaps more importantly, in most countries CPI, being a 'politically visible' economic indicator, is susceptible to manipulation. ${ }^{22}$

Most of the previous studies have typically used either of two other indicators, although the theoretical reasoning behind the particular measurement choice is seldom made explicit. One, which is perhaps the most widely used, particularly in publications of the IMF and the World Bank, uses a trade-weighted index of consumer prices in trading partner countries for $P^{W}$ and an index of consumer prices in the given country for $P^{D}$. The use of this indicator as a proxy for the theoretical concept of a real exchange rate for developing countries is usually justified on the premise that under the low inflation conditions that prevail in developed countries (which are generally the major trading partners), producer prices and consumer prices tend to move together (Edwards 1989). The other is the J.P. Morgan index, which uses wholesale non-food manufacturing prices for both world and domestic prices. This measure may thus be viewed as an indicator of the international competitiveness of manufacturing goods produced in the given country. It is not a measure of internal competitiveness (the relative profitability of domestic production of tradables compared with non-traded goods and services), the concept of real exchange rate, which is theoretically more appropriate for the present analysis. Wholesale prices of traded goods generally adjust to exchange rate changes and the dismantling of trade barriers and are thus likely to deviate from the price trends of non-traded goods.

22 We owe this point to Richard Cooper. 


\section{REFERENCES}

Athreye, S. and S. Kapur (2001), 'Private Foreign Investment in India: Pain or Panacea?', World Economy, 24(3), 399-424.

Athukorala, P. (2001), Crisis and Recovery in Malaysia: The Role of Capital Controls (Cheltenham: Edward Elgar).

Athukorala, P. (2003), 'Foreign Direct Investment in Crisis and Recovery: The East Asian Experience', Australian Economic History Review (forthcoming).

Athukorala, P. and P. G. Warr (2002), 'Vulnerability to a Currency Crisis: Lessons from the Asian Experience', World Economy, 25(1), 33-57.

Calvo, G.. A.(1991), 'The Peris of Sterilization', IMF Staff Papers, 31(4), 921-26.

Calvo, G. A., L. Leiderman and C. M. Reinhart (1994), 'Capital Inflows to Latin America: The 1970s and 1990s', in Edmar L. Bacha (ed.), Economics in a Changing World, London: Macmillan, 123-148.

Calvo, G. A., L. Leiderman and C. M. Reinhart (1996), 'Inflows of Capital to Developing Countries in the 1990s', Journal of Economic Perspectives, 10(2), 123-39.

Corbo, V. and L. Hernandez (2000), 'Private Capital Inflows and the Role of Economic Fundamentals', in Felipe Larian B. (eds.), Capital Flows, Capital Controls, and Currency Crises in Latin America in the 1990s, Ann Arbor: University of Michigan Press, pp. 83-100.

Corbo, V. and S. Fisher (1995), 'Structural Adjustment, Stabilisation and Policy Reforms: Domestic and International Finance' in Jerry Behrman and T. N. Srinivasan (eds), Handbook of Development Economics, Volume III, pp. 2846-2924.

Corden, W. M. (1960), 'The Geometric Representation of Policies to Attain Internal and External Balance', Review of Economic Studies, 18(1), 1-22.

Corden, W. M. (1994), Economic Policy, Exchange Rates and the International System, Oxford: Oxford University Press.

Corden, W. M. (1996), 'Pragmatic Orthodoxy: Macroeconomic Policies in Seven East Asian Economies', Occasional Paper 61, San Francisco, CA: International Center for Economic Growth.

Corden W. M. (2002), Too Sensational: On the Choice of Exchange Rate Regimes, Cambridge, Mass.: MIT Press. 
Dornbusch, R. and A. Warner (1994), 'Mexico: Stabilization, Reform, and No Growth', Brooking Papers in Economic Activity 1, 252-315.

Edwards, S. (1989), Real Exchange Rates, Devaluation and Adjustment: Exchange Rate Policies in Developing Countries (Cambridge, Mass: MIT Press).

Edwards, Sebastian (1995), Crisis and Reform in Latin America: From Despair to Hope, New York: Oxford University Press.

Edwards, S. (2000), 'Capital Flows, Real Exchange Rates, and Capital Controls: Some Latin American Experiences' in Sebastian Edwards (ed.), Capital Flows and the Emerging Economies: Theory, Evidence and Controversies, Chicago: University of Chicago Press, pp. 197-253.

Edwards, S. and M. A. Savastano (2000), 'Exchange Rate in Emerging Economies: What Do We Know? What Do We Need to Know?', in Anne O Krueger (ed), Economic Policy Reforms: The Second Stage, Chicago: University of Chicago Press, 453-510.

Feenstra, R. C. (2000), 'Facts and Fallacies about Foreign Direct Investment', in Martin Feldstein (ed.), International Capital Flows, Chicago: University of Chicago Press, pp. 331-350.

Fernandez-Arias E. and P. Montiel (1996), 'The Surge in Capital Inflows to Developing Countries: An Analytical Overview', World Bank Economic Review, 10(1), 51-77.

Garnaut, R. (1999), 'Exchange Rates in the East Asian Crisis' in H.W. Arndt and Hal Hill (eds.), Southeast Asia's Economic Crisis: origins, Lessons and the Way Forward, Singapore: Institute of South East Asian Studies, 93-106.

Gavin, M., R. Hausmann, and L. Leiderman (1996), 'The Macroeconomics of Capital Flows to Latin America', in Ricardo Hausmann and Liliana Rojas-Suarez (eds.), Volatile Capital Flows: Taming Their Impact on Latin America, Washington DC: Inter-American Bank, pp. 1-60.

IMF (International Monetary Fund) (1995 and 2001), International Capital Markets: Developments, Prospects and Key Policy Issues, Washington DC: IMF.

Ito, T. (2000), Capital Flows in Asia', in Sebastian Edwards (ed.), Capital Flows and the Emerging Economies: Theory, Evidence and Controversies, Chicago: University of Chicago Press, pp. 255-297.

Kaminsky, G., S. Lizondo and C. M. Reinhart (1997), 'Leading Indicators of Currency Crises', IMF Working Paper WP/97/79 (Washington DC: IMF). 
Krueger, Anne O. (1997) 'Trade Policy and Economic Development: How We Learn’, American Economic Review, 87(1): 1-22.

Larian B. F. (2000), 'Capital Flows, Capital Controls, and Currency Crises in Latin America', in Felipe Larian B. (eds.) Capital Flows, Capital Controls, and Currency Crises in Latin America in the 1990s, Ann Arbor: University of Michigan Press, pp. 1-16.

Lipsey, R. E. (2000), 'The Role of Foreign Direct Investment in International Capital Flows' Feldstein, Martin (ed) (2000), International Capital Flows, Chicago: University of Chicago Press, 307-330..

Little, I. M. D., Richard N. Cooper, W.M. Corden and S. Rajapatirana (1993), Boom, Crisis and Adjustment: The Macroeconomic Experiences of Developing Countries, Oxford: Oxford University Press.

Reisen, H. (2000), Pensions, Savings and Capital Flows: From Ageing to Emerging Markets, Cheltenham: Edward Elgar.

Sachs, J.D. (1985) 'External Debts and Macroeconomic Performance in Latin America and East Asia', Brooking Papers on Economic Activity, 2: 523-64.

Sachs, J.D. and A. Warner, A. (1995) 'Economic Reforms and the Process of Global Integration', Brookings Papers on Economic Activity, 25th Anniversary Issue: $1-95$.

Sachs, J. D., A. Tornell and A.Velasco (1996), 'Financial Crises in Emerging Markets: The Lessons from 1995', Brookings Papers on Economic Activity, 1, 147-215.

Stiglitz, J. E. (2000), 'Capital Market Liberalization, Economic Growth, and Instability', World Development, 28(6), 1075-1086.

Williamson, J. and M. Mahar (1998), 'A Survey of Financial Liberalization', Essays in International Finance, No. 211, Princeton NJ, Department of Economics, Princeton University.

Warr, P. G. (1986), 'Indonesia's other Dutch Disease: Economic Effects of the Petroleum Boom', in J.P. Neary and S. van Wijnbergen (eds.) Natural Resources and the Macroeconomy (Oxford: Basil Blackwell), 288-320.

World Bank (1997), Private Capital Flows to Developing Countries: The Road to Financial Integration, New York: Oxford University Press

Table 1: Net Capital Inflow ${ }^{1}$ to Selected Asian and Latin American Countries: 1985-1999 (Percent of GDP)-

\begin{tabular}{lllllll}
$1985-8$ & $1990-9$ & & & & & \\
$9^{2}$ & $4^{2}$ & 1995 & 1996 & 1997 & 1998 & 1999 \\
\hline
\end{tabular}

(a) Asia 


\section{China}

FDI

Portfolio investment

Bank loans and other

India

FDI

Portfolio investment

Bank loans and other

Indonesia

FDI

Portfolio investment

Bank loans and other

Korea

FDI

Portfolio investment

Bank loans and other

Malaysia

FDI

Portfolio investment

Bank loans and other

Philippines

FDI

Portfolio investment

Bank loans and other

\section{Singapore}

FDI

Portfolio investment

Bank loans and other $\begin{array}{lllllll}1.71 & 1.02 & 2.98 & 2.98 & -0.12 & -2.62 & -0.71\end{array}$

$\begin{array}{lllllll}0.51 & 2.56 & 4.83 & 4.63 & 4.61 & 4.26 & 3.73\end{array}$

$\begin{array}{llllllll}0.41 & 0.23 & 0.11 & 0.21 & 0.77 & -0.39 & -1.13\end{array}$

$\begin{array}{lllllll}0.99 & -0.24 & 0.58 & 0.02 & -3.06 & -4.53 & -1.83\end{array}$

$\begin{array}{lllllll}2.14 & 2.25 & 1.33 & 2.58 & 1.99 & 2.33 & 2.08\end{array}$

$\begin{array}{lllllll}0.00 & 0.12 & 0.56 & 0.57 & 0.83 & 0.61 & 0.46\end{array}$

$\begin{array}{lllllll}0.00 & 0.47 & 0.44 & 1.03 & 0.61 & -0.14 & 0.51\end{array}$

$\begin{array}{lllllll}2.12 & 1.52 & 0.07 & 1.48 & 0.87 & 1.54 & 1.04\end{array}$

$\begin{array}{lllllll}2.53 & 3.26 & 3.96 & 5.35 & -1.51 & -6.22 & -2.70\end{array}$

$\begin{array}{llllllll}0.49 & 1.06 & 1.85 & 2.46 & 2.09 & -0.32 & -2.00\end{array}$

$\begin{array}{lllllll}-0.02 & 0.64 & 2.03 & 2.20 & -1.22 & -1.50 & -1.27\end{array}$

$\begin{array}{lllllll}2.87 & 2.01 & 1.19 & 0.11 & -1.14 & -5.88 & -0.94\end{array}$

$\begin{array}{lllllll}-2.63 & 1.57 & 3.18 & 4.69 & -3.11 & -4.61 & 2.16\end{array}$

$\begin{array}{lllllll}-0.11 & -0.20 & -0.36 & -0.45 & -0.34 & 0.21 & 1.26\end{array}$

$\begin{array}{lllllll}0.08 & 1.50 & 2.39 & 2.90 & 3.02 & -0.39 & 2.26\end{array}$

$\begin{array}{llllllll}-2.48 & 0.45 & 1.40 & 2.03 & -4.74 & -2.48 & -0.49\end{array}$

$\begin{array}{lllllll}0.51 & 11.11 & 7.75 & 6.92 & 2.06 & 0.67 & -10.03\end{array}$

$\begin{array}{rrrrrrr}2.33 & 7.10 & 4.70 & 5.04 & 5.13 & 2.98 & 1.97\end{array}$

$\begin{array}{rrrrrrr}1.04 & -1.08 & -0.49 & -0.27 & -0.25 & 0.39 & 1.02\end{array}$

$\begin{array}{lllllll}-2.83 & 3.51 & 4.39 & 4.63 & -2.69 & -6.89 & -11.40\end{array}$

$\begin{array}{lllllll}2.31 & 6.32 & 4.34 & 10.01 & 1.53 & -0.41 & -5.55\end{array}$

$\begin{array}{rrrrrrr}1.04 & 1.28 & 1.46 & 1.61 & 1.32 & 3.25 & 0.57\end{array}$

$\begin{array}{llllllll}0.18 & 0.11 & 1.61 & 6.42 & 0.72 & -1.42 & 6.28\end{array}$

$\begin{array}{llllllll}0.22 & 4.84 & 4.10 & 5.58 & 5.87 & -1.09 & -8.08\end{array}$

$\begin{array}{lllllll}2.66 & 0.37 & -7.00 & -7.12 & -9.48 & -21.82 & -20.08\end{array}$

$\begin{array}{rrrrrrr}9.34 & 6.35 & 1.11 & 2.24 & -0.82 & 8.48 & 3.58\end{array}$

$\begin{array}{lllllll}-0.45 & -3.91 & -8.82 & -12.07 & -13.65 & -9.48 & -8.34\end{array}$

\begin{tabular}{lllllll}
-6.54 & -1.41 & 1.95 & 3.98 & 0.29 & -25.02 & -15.91 \\
\hline
\end{tabular} 
Table 1 (continued)

\begin{tabular}{lrrrrrrrr}
\hline & & & & & & & -9.13 \\
\hline Thailand & 5.04 & 9.94 & 12.31 & 9.24 & -10.08 & -15.14 & 4.85 \\
$\quad$ FDI & 1.11 & 1.64 & 0.70 & 0.77 & 2.32 & 6.42 & \\
Portfolio investment & 1.17 & 1.35 & 2.43 & 1.94 & 3.00 & 0.32 & 0.06 \\
Bank loans and other & 1.95 & 6.59 & 9.89 & 7.97 & -13.39 & -19.51 & -14.06
\end{tabular}

(b) Latin America

Argentina

FDI

Portfolio investment

Bank loans and other

Brazil

FDI

Portfolio investment

Bank loans and other

Chile

FDI

Portfolio investment

Bank loans and other

Colombia

FDI

Portfolio investment

Bank loans and other

Mexico

FDI

Portfolio investment

Bank loans and other

Peru

FDI

Portfolio investment

Bank loans and other $\begin{array}{lllllll}-1.99 & 2.32 & 1.04 & 3.59 & 5.38 & 6.30 & 5.11\end{array}$

$\begin{array}{lllllll}0.76 & 1.18 & 1.59 & 1.96 & 1.88 & 1.66 & 8.09\end{array}$

$\begin{array}{lllllll}-0.74 & 3.70 & 0.72 & 3.61 & 3.52 & 2.94 & -2.28\end{array}$

$\begin{array}{lllllll}-1.83 & -2.47 & -0.54 & -1.40 & 0.30 & 1.74 & -0.36\end{array}$

$\begin{array}{lllllll}-4.85 & 7.51 & 3.90 & 8.77 & 9.18 & 2.74 & -1.00\end{array}$

$\begin{array}{lllllll}3.10 & 2.02 & 3.40 & 5.06 & 4.46 & 2.52 & 6.45\end{array}$

$\begin{array}{lllllll}-0.04 & 1.25 & 0.05 & 1.60 & 3.15 & -1.13 & 0.19\end{array}$

$\begin{array}{lllllll}-7.82 & 4.10 & 0.24 & 3.06 & 2.17 & 2.97 & -7.87\end{array}$

$\begin{array}{lllllll}-4.85 & 7.51 & 3.90 & 8.77 & 9.18 & 2.74 & -1.00\end{array}$

$\begin{array}{lllllll}3.10 & 2.02 & 3.40 & 5.06 & 4.46 & 2.52 & 6.45\end{array}$

$\begin{array}{lllllll}-0.04 & 1.25 & 0.05 & 1.60 & 3.15 & -1.13 & 0.19\end{array}$

$\begin{array}{lllllll}-7.82 & 4.10 & 0.24 & 3.06 & 2.17 & 2.97 & -7.87\end{array}$

$\begin{array}{lllllll}2.21 & 1.87 & 4.96 & 6.67 & 5.76 & 3.86 & -0.29\end{array}$

$\begin{array}{lllllll}1.47 & 1.37 & 0.77 & 2.87 & 4.53 & 2.46 & 1.17\end{array}$

$\begin{array}{lllllll}0.13 & 0.32 & 1.55 & 1.71 & 0.85 & 1.83 & -0.89\end{array}$

$\begin{array}{lllllll}1.06 & -0.06 & 2.52 & 1.99 & 1.20 & 0.02 & -0.39\end{array}$

$\begin{array}{lllllll}-0.35 & -5.66 & -0.55 & -0.70 & -1.86 & -3.73 & -2.92\end{array}$

$\begin{array}{lllllll}1.20 & 1.53 & 3.33 & 2.76 & 3.20 & 2.69 & 2.46\end{array}$

$\begin{array}{lllllll}-0.45 & 3.42 & -3.63 & 4.20 & 1.08 & -0.32 & 2.07\end{array}$

$\begin{array}{lllllll}-1.41 & 1.50 & -3.37 & -5.12 & 0.52 & 2.04 & -0.82\end{array}$

$\begin{array}{lllllll}-5.34 & 2.06 & 6.59 & 7.70 & 8.87 & 3.99 & 1.85\end{array}$

$\begin{array}{lllllll}0.08 & 1.79 & 3.89 & 5.82 & 2.88 & 3.30 & 3.79\end{array}$

$\begin{array}{lllllll}0.00 & 0.33 & 0.30 & 0.32 & 0.26 & -0.61 & -0.72\end{array}$

\begin{tabular}{lllllll}
-3.74 & -1.34 & 1.48 & -0.07 & 6.21 & 0.14 & -1.87 \\
\hline
\end{tabular} Note:

1. Including errors and omissions.

2. Annual average.

Source: Compiled from IMF, International Financial Statistics database. 
Table 2: Capital Inflow Episodes of Selected Asian and Latin American Countries: Timing, Cumulative Change in Inflows, Maximum Annual Inflow and Change in Real Exchange Rate (RER).

\begin{tabular}{|c|c|c|c|c|}
\hline & $\begin{array}{l}\text { Capital Inflow } \\
\text { episode }^{1}\end{array}$ & $\begin{array}{l}\text { Change in net } \\
\text { capital inflow } \\
(\% \text { of GDP) }\end{array}$ & $\begin{array}{l}\text { Maximum } \\
\text { annual inflows } \\
\text { during the } \\
\text { episode }\end{array}$ & $\begin{array}{l}\text { Change in } \\
\operatorname{RER}^{2,3} \\
(\%)\end{array}$ \\
\hline \multicolumn{5}{|l|}{ Asia } \\
\hline China, PR & $1993-96$ & 5.0 & 4.4 & 6.8 \\
\hline India & 1991-94 & 0.6 & 3.8 & 22.0 \\
\hline Indonesia & $1990-96$ & 1.6 & 5.4 & -8.1 \\
\hline Korea, Rep. of & $1990-96$ & 5.5 & 4.7 & -7.4 \\
\hline Malaysia & $1989-96$ & 5.7 & 21.4 & -6.9 \\
\hline Philippines & $1989-96$ & 4.8 & 10.0 & -11.2 \\
\hline Singapore & $1987-92$ & 7.1 & 5.8 & -2.3 \\
\hline Thailand & $1987-95$ & 9.1 & 12.4 & -5.5 \\
\hline \multicolumn{5}{|l|}{ Latin America } \\
\hline Argentina & 1990-93 & 8.8 & 8.1 & -43.5 \\
\hline Brazil & $1992-96$ & 3.9 & 4.4 & -14.7 \\
\hline Chile & 1989-97 & 5.6 & 9.3 & -18.6 \\
\hline Colombia & $1992-96$ & 3.9 & 6.7 & -18.1 \\
\hline Mexico & 1989-93 & 6.9 & 7.8 & -33.8 \\
\hline Peru & $1992-97$ & 9.0 & 8.8 & -19.7 \\
\hline
\end{tabular}

Notes

1. The period during which the economy experienced a significant surge in net capital inflows.

2. Percentage change in average net capital inflow to GDP ratio during the episode from the average for the three proceeding years.

3 . Percentage change in the average RER $(1990=100)$ during the episode relative to the average for the three preceding years. A decrease in the index denotes appreciation.

Source: As for Table 2. 


\begin{tabular}{|c|c|c|}
\hline & Equation 1 & Equation 2 \\
\hline Variable $^{2}$ & Parameter (t-ratio) & Parameter (t-ratio) \\
\hline Constant & $+4.72(41.96) * * *$ & $+4.71(56.22) * * *$ \\
\hline Foreign direct investment $(F D I)$ & $+0.32(3.40)^{* * *}$ & $+0.29(3.35)^{* * *}$ \\
\hline Capital inflow excluding FDI $(O C F W)$ & $-0.55(2.50)^{*}$ & $-0.56(2.60)^{* *}$ \\
\hline Excess money growth $(E X M S)$ & $-0.18 \quad(0.84)$ & \\
\hline Government expenditure (GEXP) & $-3.18 \quad(3.14)^{* * *}$ & $-3.17 \quad(5.53) * * *$ \\
\hline Change in nominal exchange rate (DNER) & $+0.61 \quad(2.50)^{* *}$ & $+0.50(2.48)^{* *}$ \\
\hline Openness $(O P E N)$ & $+0.15 \quad(2.67)^{* *}$ & $+0.15(2.62)^{* *}$ \\
\hline Slope dummy variables for Latin America (LA) & & \\
\hline$L A * O C F W$ & $-1.16(2.91)^{* * *}$ & $-1.14(2.95)^{* * *}$ \\
\hline$L A^{*} F D I$ & $-0.54(3.37)^{* * *}$ & $-0.52(3.35)^{* * *}$ \\
\hline$L A * E X M S$ & $-0.19(0.83)$ & \\
\hline$L A * G E X P$ & $-0.05 \quad(0.04)$ & \\
\hline$L A * D N E R$ & $-0.56(2.08)^{* *}$ & $-0.45(2.18)^{* *}$ \\
\hline$L A * O P E N$ & $-0.18(2.42)^{* *}$ & $-0.18(2.49)^{* *}$ \\
\hline$N$ & 224 & 224 \\
\hline$\overline{R^{2}}$ & 0.50 & 0.52 \\
\hline$F$ & 9.91 & 11.35 \\
\hline$S E$ & 0.14 & 0.14 \\
\hline$S I V \chi^{2}(11)$ & $132.35 * * *$ & $131.46 * * *$ \\
\hline$R E S E T-\chi^{2}(1)$ & $0.10^{* * * *}$ & $0.09 * * *$ \\
\hline $\mathrm{JBN}, \chi^{2}-(2)$ & $3.26 * * *$ & $3.2 * * *$ \\
\hline $\mathrm{ARCH}-\chi^{2}(1)$ & $0.88 * * *$ & $0.83 * * *$ \\
\hline
\end{tabular}

Notes

* Country intercept dummies are not reported. The figure in parentheses underneath each coefficient is the t-ratio of the coefficient. The level of statistical significance denoted as: $*=10 \%, * *=5 \%$ and $* * *=1 \%$.

Test Statistics

SE Standard error of the regression.

SIV Sargan's general test of misspecification in instrumental variable (IV) estimation..

RESET Ramsey test for functional form miss-specification.

$J B N$ Jarque-Bera test for the normality of residuals.

$A R C H$ Engle's autoregressive conditional heteroscedasticity test.. 
Table 4: Change in Explanatory Variable During the Capital Inflow Boom ${ }^{1}$ Compared to the Mean Level for the Sample Period (1985-2000)

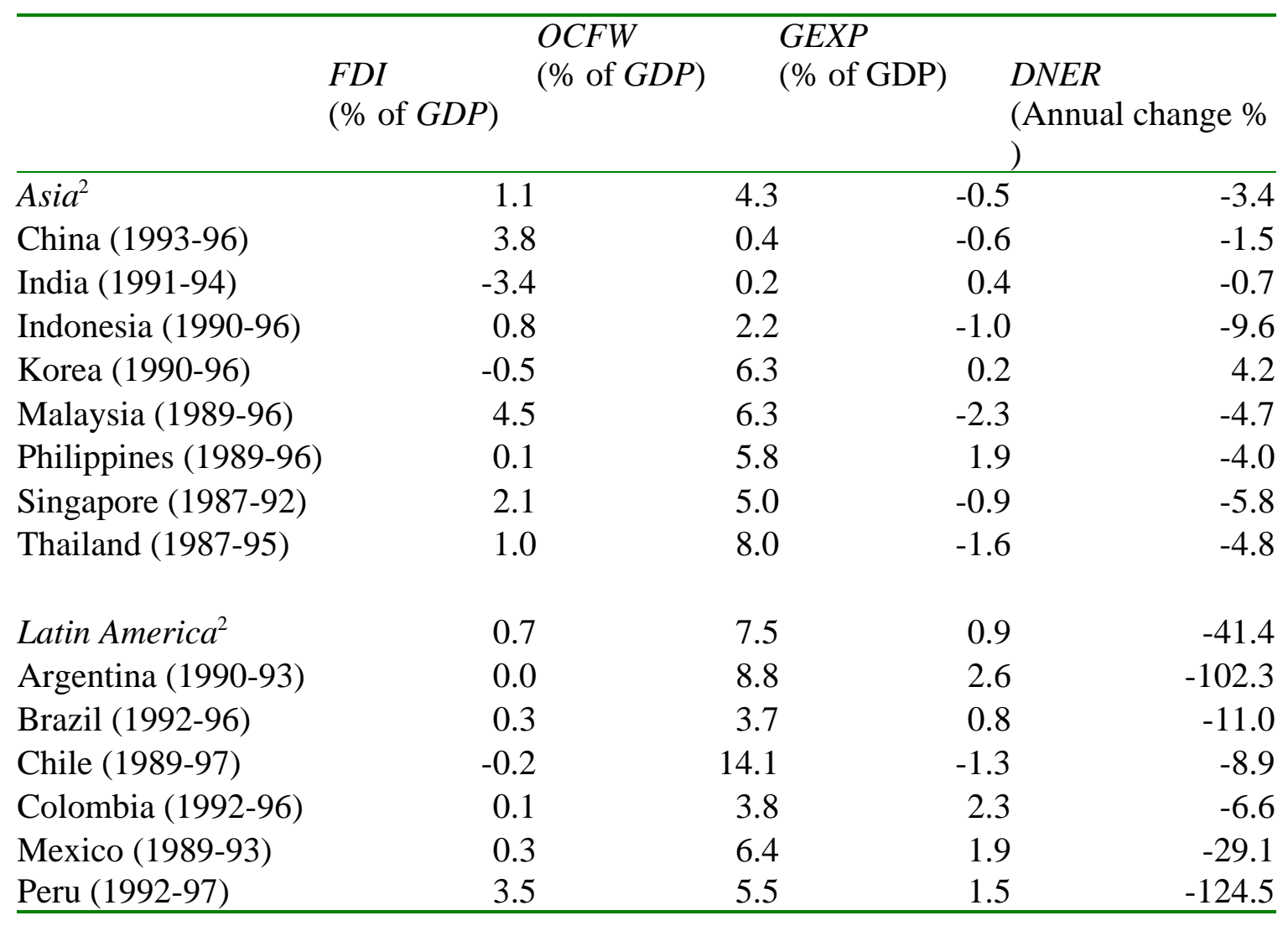

Notes

1. Capital inflow boom is given in brackets net to the country name in column 1 .

2. Simple average for the listed countries.

Source: See Figure 2. 


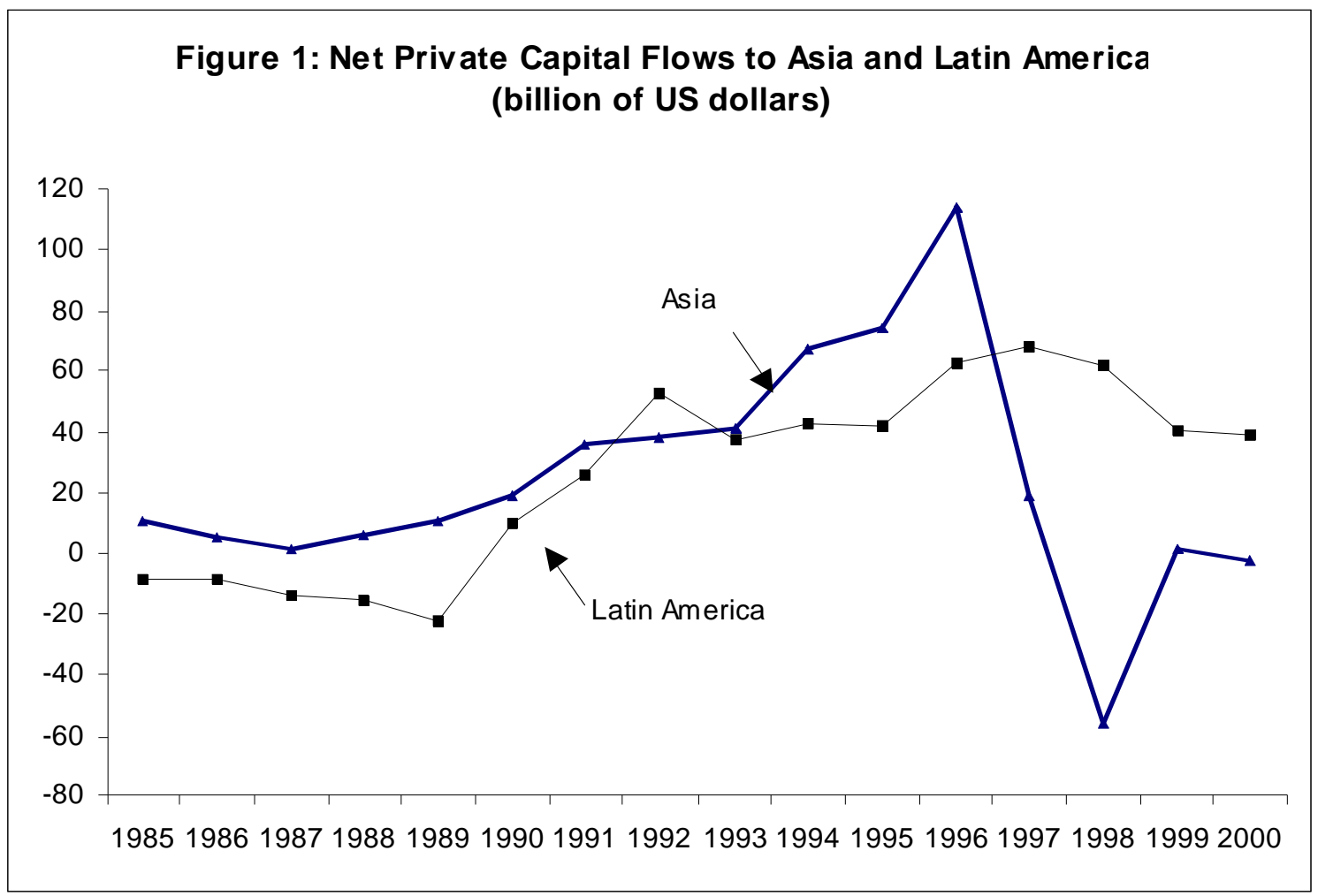

Source: IMF 1995 and 2001. 
Figure 2: Net Capital Inflows (percentage of GDP) and the Real Exchange Rate $(1990=100)$ for selected Asian and Latin American countries (1985-2000)

(a)Asia
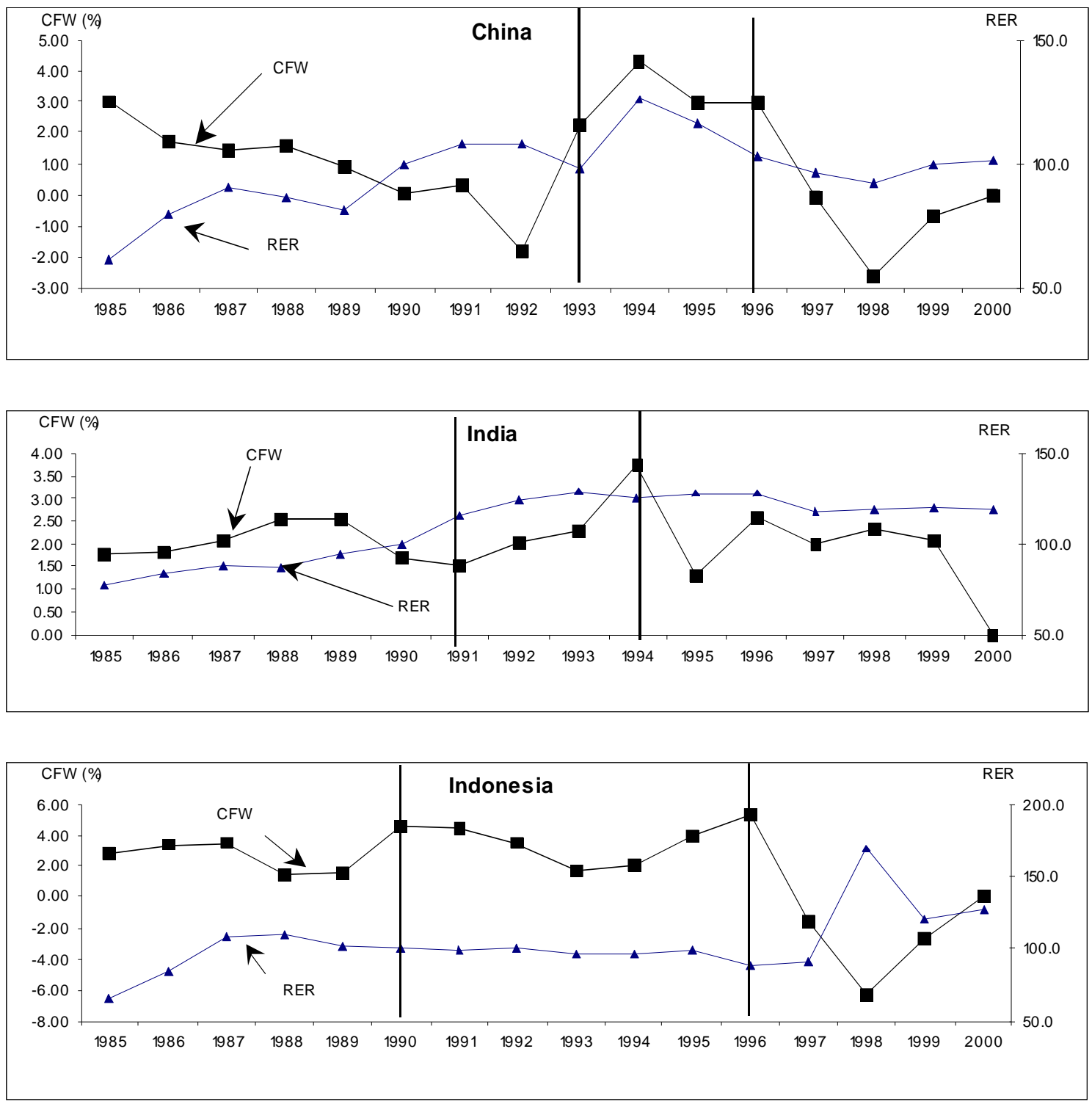

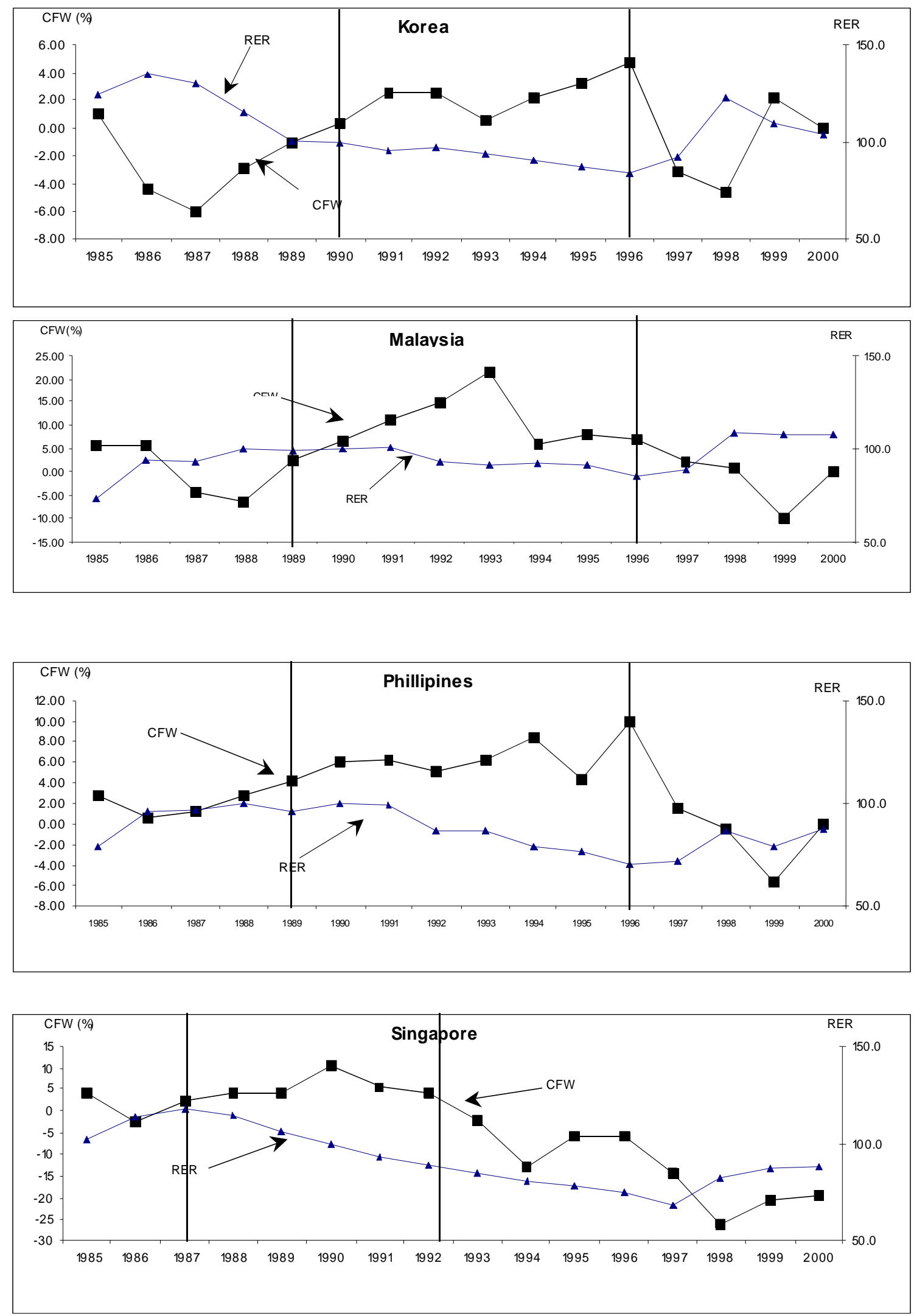


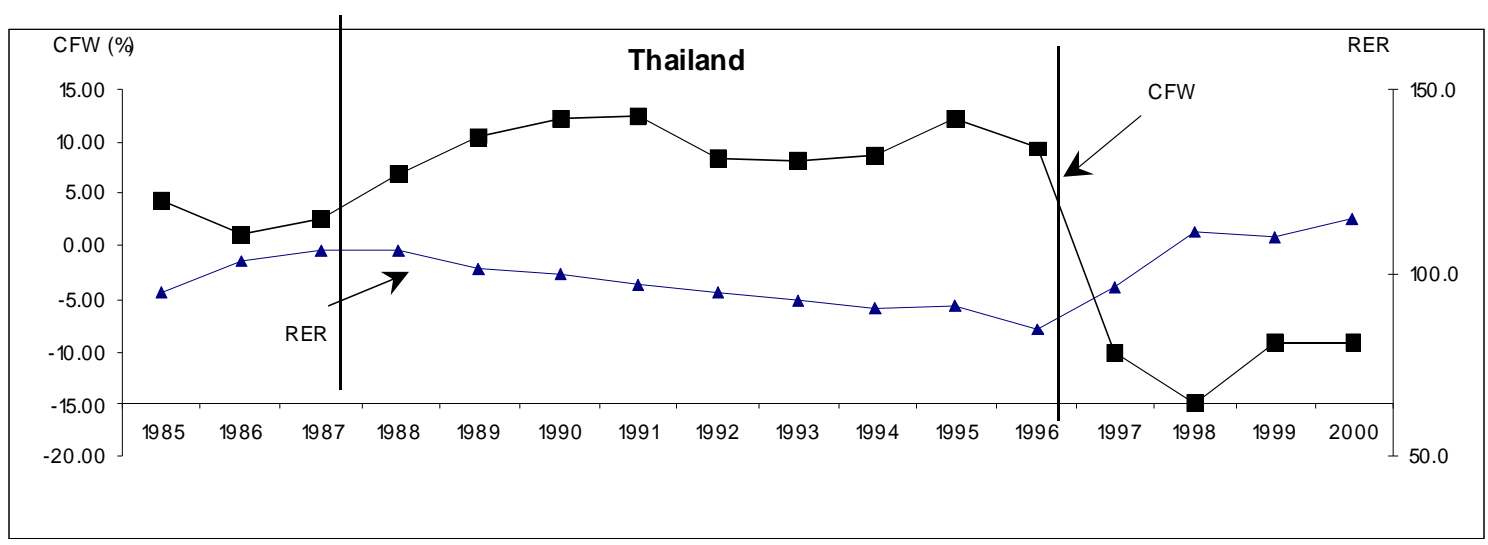

(b) Latin America
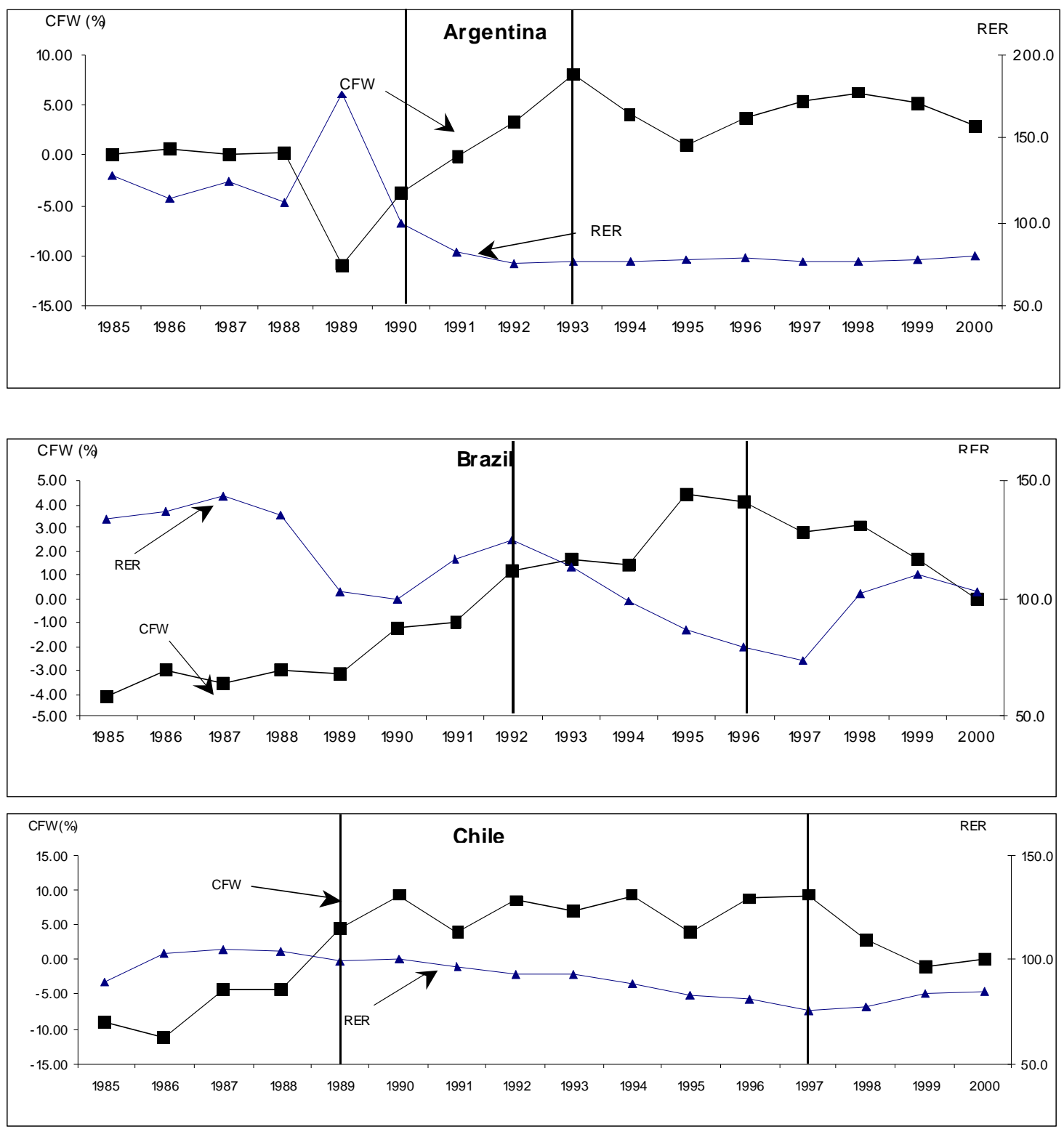

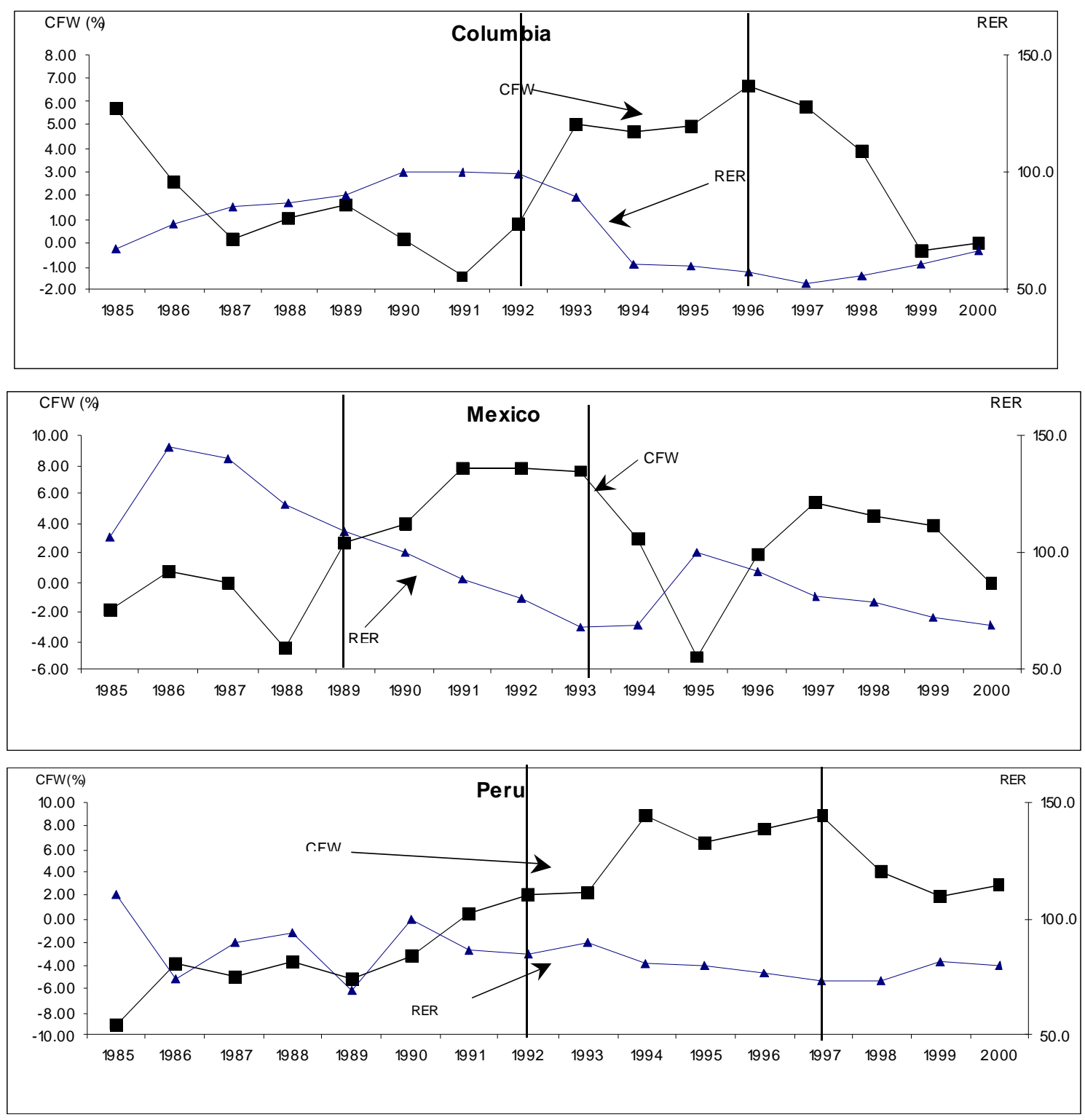

Note: * vertical lines denote the beginning and end of capital inflow episodes. The correlation coefficient estimated between change in RER and capital inflow (\% of GDP): China $=0.25$; India $=0.19$; Indonesia $=-0.72 ;$ Korea $=-0.75 ;$ Malaysia $=0.40 ;$ Philippines $=-0.09 ;$ Singapore $=-0.58 ;$ Thailand $=0.51$; Argentina $=0.83 ;$ Brazil $=0.65 ;$ Chile $=0.33 ;$ Colombia $=0.55 ;$ Mexico $=0.67 ;$ and Peru $=0.84$.

Source : Based of data complied from IMF, International Financial Statistics database. 